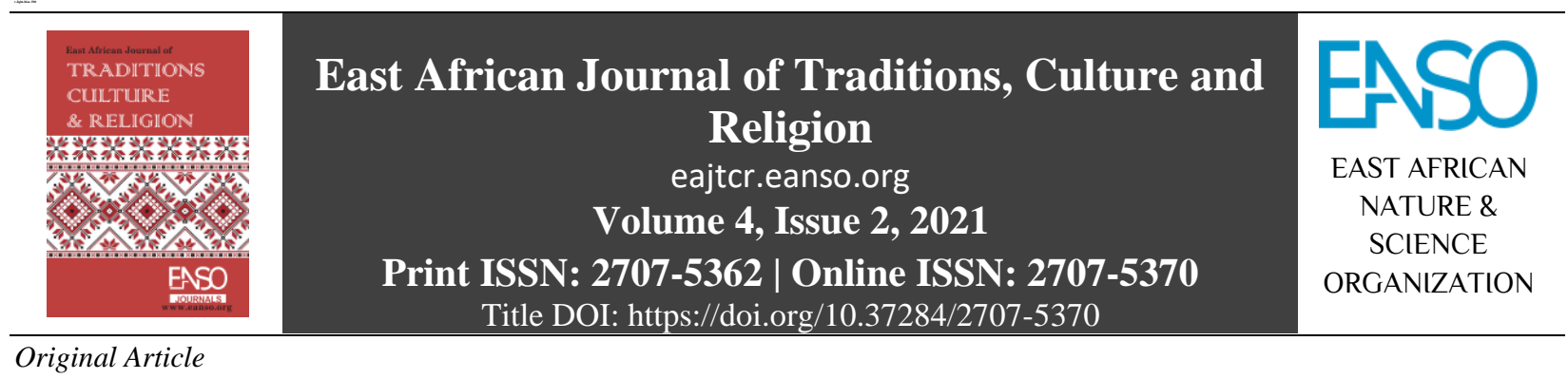

\title{
A Literature Review on Ubuntu Concept as a Panacea for African Ecclesiology: A Case Study of Harvest Revival Ministry Churches in Kenya.
}

\author{
Peter Lee Ochieng Oduor, PhD \\ ${ }^{1}$ Africa International University, P.O Box 24686, 00502, Nairobi, Kenya. \\ Author Correspondence Email: pastoroduorlee@gmail.com.
}

Article DOI: https://doi.org/10.37284/eajtcr.4.2.514

\section{Date Published: ABSTRACT}

20 December 2021 The study seeks to examine the approaches taken currently with regard to scholarship on ecclesiology from the patristic era, the medieval era to that of the

Keywords: reformation and beyond. The study evaluates the various ecclesiological approaches of various confessional traditions that have defined ecclesiology over time. In

Ubuntu, progression, the study examines contextual ecclesiologies with a focus on three Ecclesiology, specific cultural geographical environments of Africa, Asia, and Latin America. Patristic, This is because of the significance that these regions play in the current global shift Medieval, within Christendom. African ecclesiology has been the centre of focus in an attempt Reformation, to link all the discussed ecclesiologies with the African Christian thought. The study

Contextual, of people in the African setting. The study intends to expose the gap in the literature Philosophy, demonstrating that the African conceptual framework can indeed be of use in Bantu articulating theology relevant to the African world. The study was keen to evaluate the contribution towards the development and construction of an African ecclesiology using the Ubuntu concept as a remedy to solve ecclesiological problems witnessed in Africa.

\section{APA CITATION}

Oduor, P. L. O. (2021). A Literature Review on Ubuntu Concept as a Panacea for African Ecclesiology: A Case Study of Harvest Revival Ministry Churches in Kenya. East African Journal of Traditions, Culture and Religion, 4(2), 22-37. https://doi.org/10.37284/eajtcr.4.2.514

\section{CHICAGO CITATION}

Oduor, Peter Lee Ochieng. 2021. "A Literature Review on Ubuntu Concept as a Panacea for African Ecclesiology: A Case Study of Harvest Revival Ministry Churches in Kenya.". East African Journal of Traditions, Culture and Religion 4 (2), $22-37$. https://doi.org/10.37284/eajtcr.4.2.514.

\section{HARVARD CITATION}

Oduor, P. L. O. (2021) "A Literature Review on Ubuntu Concept as a Panacea for African Ecclesiology: A Case Study of Harvest Revival Ministry Churches in Kenya.”, East African Journal of Traditions, Culture and Religion, 4(2), pp. 22-37. doi: 10.37284/eajtcr 4.2.514. 


\section{IEEE CITATION}

P. L. O. Oduor, "A Literature Review on Ubuntu Concept as a Panacea for African Ecclesiology: A Case Study of Harvest Revival Ministry Churches in Kenya.”, EAJTCR, vol. 4, no. 2, pp. 22-37 Dec. 2021.

\section{MLA CITATION}

Oduor, Peter Lee Ochieng. "A Literature Review on Ubuntu Concept as a Panacea for African Ecclesiology: A Case Study of Harvest Revival Ministry Churches in Kenya." East African Journal of Traditions, Culture and Religion, Vol. 4, no. 2, Dec. 2021, pp. 22-37, doi:10.37284/eajtcr.4.2.514.

\section{INTRODUCTION}

Research on the Ubuntu concept that is a dominant philosophy among African people would serve as a panacea in the task of African ecclesiology. This process would go a long way in the noble task of the construction, development, and establishment of formidable African ecclesiology that would in the long run necessitate the growth of the African church. This sense of community is a true reflection of a deeply rooted conviction among the African people that embrace the ideology that it is only in the community framework that people in general and Christians, in particular, find meaning in their life according to Antwi (1996, p.10). Accurately captured by Kärkkäinen (2002, p. 195) is the essence of communal living as a technology of God to promote and sustain quality life for both the individual and the society in general. Ubuntu stands for the notion that there is nothing in an individual capacity that there can be no attainment of development as well as the acquisition of any amount of progress in an isolated context because one can only explore or attain humanity through the avenue of interconnection with others because it is this collective inclusivity that grants power to the individual according to Omenyo (Fall, 2000, p. 236).

Mbiti (1989, p.106) captures the principle in a nutshell that "I am because you are, and since you are, therefore I am." This study intends to evaluate the extent to which available literature on the subjects of ecclesiology and Ubuntu are committed to addressing the concept of ecclesiology in African Christian thought. It is in the quest to develop this ideological thought that this work joins Waliggo in Ed. John Mary Waliggo (1990, p.250) to ascertain the advancement of a proposal to spearhead the clan model as a more applicable structural outfit in contrast to the individualistic Western structural model for ecclesiological conversations and dialogue in Africa. The consideration that there can be the capitalization on the part of the African church to thrive in her reassuring nature of the church as a family, clan, and kinship will be substantial in the structuring of the Christian communities identical of the African spirit of cohesiveness and inclusivity as she seeks to emulate the apostolic church in the book of Acts 2:42 that was predominantly communal as is expressed by Omenyo (Fall, 2000, p. 238). We intend to capture the relationship of this usage of the communal concept of the African people as a means to establish strong and impactful Christian communities in the continent of Africa.

In this study we begin by locating the research within the wider concept of the scholarship on ecclesiology with regard to how it has been constructed within different church traditions from a global dimension as we build on looking at contextual ecclesiology with a focus on African ecclesiology in an attempt to link all the discussed ecclesiologies with the African Christian thought. We also wish to review the scholarship engagement that has been conducted with regard to the Ubuntu concept. Our interest in this segment will be to capture the concept of the humanness of people in the African setting. We shall be keen to evaluate literature that captures the belief of the African in the areas of family, clan, and kinship in line with the Ubuntu concept. This is very significant because of how it captures the philosophy of the Africans and answers pertinent questions as to why Africans respond in a certain way to certain issues.

\section{Advent of Ecclesiological Scholarship}

Any meaningful conversation of ecclesiology begins with the paramount understanding of not only the composure of the church but also identifiable traits of a true and genuine church of Jesus Christ. Volf (1998, p. 129) has correctly stated that if one is to have meaningful conversations and dialogues about ecclesiality, there must be the overriding knowledge of not only what the church is, but also the marks of identifying a concrete 
church externally as well as a church organization as well as monitoring the presence and positioning of the church.

\section{Ecclesiology in Patristic Era}

The ecclesiological scholarship is not a discipline that came into the limelight of Christian theology just the other day but is one that has existed for a time and has experienced changes in its faces in different historical points. When we deliberate on the historical perspective of the discipline of ecclesiology one can be tempted to have a false notion the doctrine of the church did not exist as a matter of significance until the reformation era.

Many have thought along these lines because the doctrine of the church did not gain an independent establishment as per its standing in the systematic theological radar until the time of Reformation as captured by Kärkkäinen (2002, p. 9). As a matter of fact, topics of crucial significance in our contemporary conversations within the systematic discourse of the church were accorded little or no attention (Kärkkäinen, 2002). As we commit ourselves to monitoring the historicity of the church with regard to its dogmatic formulation especially in this postmodern era the reality of Rahner's (1961, p.8) criticism comes in handy with regard to our approach. This is because we approach the historical past with questions that are not open to the test of facts and our failure to closely interrogate the past close enough 'to hear it with all the overtones with which it once resounded, overtones which at that time were not perhaps the explicit formulations of a scientific theology, but rather the echoes of preaching, faith, and Christian life.' Kärkkäinen (2002, p. 9-10) affirms that it is therefore needless to assert that in as much as ecclesiology was not accorded an independent status in scholarship in the early church or the medieval ages, the church fathers had much to say about the church as is envisioned in much of her confessions that emphasizes her connection with the Holy Spirit.

In the patristic era of the church fathers, Jáki, O.S.B (1957, p. 171,177) observes that ecclesiology has been described as more of a doctrine that was lived as opposed to one that was formulated and theologized. This is in line with the concept of Ubuntu that found integration according to
Rwelamila, Talukhaba, \& Ngowi (1999, pp.335346) in all the aspects of the day-to-day life of the African people from all the tribes in Southern, Central, Western and Eastern Africa among the people of Bantu Origin and is more envisioned in the practical dimension of the lived life as opposed to theories. Mugambi ed. (1997, p.56) asserts that African ecclesiological thought can thrive at length in an ecclesiology that goes beyond the merits of paper and is reflected on the lived life of the people by practical dimensions. After the apostolic age, the church generally followed this Pauline pattern as it came into contact with the non-Roman, nonChristian world. Kärkkäinen (2002, p. 9) is firm that the church is named in the creeds in the clause after the Holy Spirit, the Traditio apostolica of Hippolytus in the third baptismal question, the last clause in the Nicene-Constantinopolitan Creed, all failed to offer any kind of separate treatment of the church, even though they significantly facilitated our understanding of the church. Haight (2004, p. 148) observes that the Apostolic Tradition attributed to Hippolytus gives a good indication of church order in the churches which the sphere of Rome's influence between the late second century and the early forth providing a picture of church life at least in formal terms without thick description.

These Apostolic Traditions that have been attributed to Hippolytus (1962, p.56) is a manual for church order that was a response to the need to retain the ancient way of doing things against change or forgetfulness. Bradshaw (1996, p.15) affirms that in the contemporary many regards it as a compilation of material dating from the second to the early fourth century. The church fathers envisioned the church as both a visible and spiritual entity inspired by the thoughts of Augustine. This is a reality that the African folks would not find any difficult to relate with because of the definition of the community that was awake to the reality that it comprised of 'the living the dead and the yet unborn' according to Dyrness, \& Kärkkäinen (2009, p.219) and the facilitation of the composure of the church in the African ecclesial thought. Kelly (1960, p. 191-202) observes that there was minimal ecclesiology in both the Eastern and Western churches at this historical era. Spickard \& Cragg (1994, p. 56) affirms that it is in this period that we have the famous edict of Milan that extended toleration of all religions and thus decriminalized 
Christianity and according to it the same sanctions as other religions. Haight (2004, p. 201) agrees that it was in 313 that Constantine together with the Eastern Emperor issued the so-called Edict of Milan declaring the freedom of religious worship thus legitimizing the church in principle.

This edict according to Evans (1972, p.78) had a fair share of implications with regard to ecclesiological development as there was an outstanding transition that saw the church passing quickly from a context that saw her leading and exemplary bishops martyred to one that saw her leaders being guests at the emperor's table and be court advisors. Grant (1977, p. 44-65, 151-154) has identified areas such as the acquisition of church properties, construction of churches, church and clergy tax exemption, and the reception of civic status as the reward the church received from Constantine. Haight (2004, p. 202) confirms that the church was tasked with civic responsibilities such as care of the poor and also granted jurisdiction to church tribunals for settling certain legal conflicts making her become an instrument in running of society. Similarly, the African tradition placed on the community the burden of social, judicial, and legal duties to ensure that the harmony of community life was never compromised. African ecclesiology should actively engage the 'African culture in which individuals express compassion, reciprocity, dignity, humanity, and mutuality in the interests of the building and maintaining communities with justice and communalities' according to Poovan, N., Du Toit, M.K. \& Engelbrecht, A.S., (2006, p. 1-21).

One of the benefits of the edict was how the intellectual world of the Romans shifted from pagans to Christians with the key contributors being 'Augustine, Jerome and Ambrose' according to Spickard \& Cragg (1994, p. 61). Augustine is remembered for his ecclesiological contribution of trying to bring out a Christological emphasis on ecclesiology by virtue of the triple mode of the existence of Christ as incarnate, Word, and the Church and yet constituted a single, spiritual entity; he also emphasized the necessity unanimity of the church in matters faith and love; he finally contributed by stressing the inclusivity of the church to the extent that she comprises of both the sinners and the just as is noted by Kelly (1960, p. 413-417). Augustine's emphasis on ecclesiology from this analysis is the communitarian dimension that is characteristic of the church. Spickard \& Cragg (1994, p. 65) agree that the thought advanced by Augustine to highlight the sacred responsibility of the Church as a distributor of grace through the agency of baptism reinforced the character of the church as formalized and structural organization. In African thought community and relationships had a formal face and had structural dimensions such as family and clan settings that were little structurally existing entities that in their collective existence lead to the formation of a stronger entity in the name of a community. Kalilombe (1977) affirms that African ecclesiology can capitalize on the basic units of African communities in the quest for an Ubuntu ecclesiology that appreciates the new structural system whereby the basic units of the church are those smaller communities where the ordinary life of the people takes place. This would be a church model that reflects traditional family and clan structures 'based on the primary group level, on the concept of a truly fraternal community where the life and communion people have in Christ, is deeper, more personal and more intensely shared' as is explained by Mutiso-Mbinda (Spearhead 60, 1979, p. 48). Mugambi ed. (1997, p.57) on his part observes that Augustine's ecclesiology took away any easy identification of any human kingdom with God's kingdom, and an effort to distinguish the two natures of the church as the church militant on earth and the church triumphant in heaven. Haight (2004, p. 209) has correctly credited Augustine as the single most important Christian theologian in the West overwhelmingly influencing the direction taken by Christianity in the West especially in matters of the sacrament, anthropology, and the understanding of the church in the world.

Mugambi ed. (1997, p.56) captures an analysis of the characteristic signature of the church in this era was its commitment to follow the Pauline pattern as it came into contact with the non-Roman, nonChristian world in the following understanding. This picture emerges in the history of Christianity in Europe as well as North Africa and the Ethiopic countries. For instance, the Greek-speaking believers in Egypt quickly recognized the need to translate Christianity from the Greek and Jewish terminologies into the local languages of the Delta and those of the interior. Through the agency of the 
Alexandrian catechetical school and the individual contribution of church fathers as Origen and Clement, Egyptian Christians took pains to relate Christianity to prevailing native philosophy ( Mugambi J. N. K. ed., 1997). Thus the church was correctly seen as a fellowship of the people of God, capable of fulfilling the aspirations of all adherents, including those with Pharaonic religious background ( Mugambi J. N. K. ed., 1997).

\section{Ecclesiology in the Medieval Era}

Laying on the foundation of Augustine of a stringent emphasis on the element of grace, the dominant perspective of the church in the early medieval was that of capturing its external dimension. The medieval has been considered the dark ages that were characterized by matters such as crusades, intolerance, and much inquisition. The Billy Graham Centre accords the work of St. Augustine of Hippo the highest esteem especially the way it gave the church in the Middle Ages a design and a base dogmatically that had a far-reaching impact to date in the mannerism of ecclesiastical engagements of both the protestant and Roman Catholic groupings. Congar (Paris - 1950, p. 81-86), states that the external aspect that was strongly emphasized as belonging to the category of a grace resource while the culmination of the church was to raise a community of grace. There was a strong correlation between Eucharist and the Church in this dispensation.

The church during this period grows to be a strong institution in itself and the conversations were concerning powers and governance in the church. It was during this time frame that saw a transition from the governmental structure in which all bishops had been equal towards the Roman Catholic Church polity whose signature was that the bishop of Rome had an office that was exalted higher than that of other bishops. The Roman Catholic Church with regard to structure began to reflect the imperial Rome. Spickard \& Cragg (1994, p.78), agree that the structure of the church at this time reflected the administrative style of the Roman Empire rising hierarchically from the low parish priest through bishops and archbishops to the singular earthly head of the church, the pope.
The African thought on leadership was one of the central centers of power that existed to serve the best interest of the wider community. African ecclesiological thought can embrace the African understanding of kingship as is captured by Ayittey (2006, p. 209), with the king being the only one with the greatest vital force in the whole kingdom because only in that way could he serve as the mediator with the superior universe without creating any break or catastrophic upheaval within the ontological forces, thus church leadership in Africa is better understood with one leader in authority at a time. Haight (2004, p. 316) states that Thomas Aquinas in this era represents the high-water mark of theology and bears no small importance for understanding the Christian church for two reasons: his ecclesiology represents the theological dimension of church self-understanding at the apogee of medieval theology and the synthesis of the achievement of Aquinas went beyond his ecclesiology and exemplified the whole age of the theology of the schools.

Congar (1965, p. 72-73) combines the ecclesiology of Aquinas into three major themes: church as spiritcentered and ethical, church as Christ-centered, or church as institutional and sacramental. Haight (2004) is in agreement with this position in the emphasis of a pneumatic ecclesiology expressed by the Spirit's indwelling in the entity of the church both, in individual membership and corporate entity and thus makes it more of a living organism. Volf (1998, p. 129) on his part acknowledges that the presence of the Church is articulated by the presence of the Spirit of Christ who is the definite gift of God's eschatological society in history automatically constructs the church. Dulles (1982, p.158) observes that the whole purpose of the church as Saint Thomas conceives it is to unite with God. This union takes place primarily through sanctifying grace, which is effectively communicated by the sacraments.

Haight (2004, p. 331) further explains on the same that the celebration of the Eucharist took a central role in the existence of the church as every Sunday, saw the church from the Cathedral to the smallest chapel celebrate it. It was also coupled by the belief in Christ's presence in the popular imagination that was towards realism. Lynch (2014, p.281) has written more specific details as to how it was 
conducted citing that in the celebration of the mass, the priest stood with his back on the congregation, often behind a screen that partly or wholly blocked the people's view. He is also said to have spoken in Latin in a lowered voice with the laypeople encouraged to embrace a culture of worship of an event that was key in the church in similar magnitude and scope as was the physical presence of the Saviour.

\section{Ecclesiology in the Reformation and Beyond}

This is a significant period in ecclesiological history because the first comprehensive treatment of ecclesiological discourses was written and it's instructive to see how slowly the consciousness of a need for a separate discussion of the same emerged. The first separate treatments on the church go back to the fifteenth century according to Kärkkäinen $(2002,10)$. The key proponents in this age were Martin Luther, John Calvin, and Ulrich Zwingli. Martin Luther is accredited for tearing down the excessive privileges that were attached to the clergy at the expense of the laity. George (1988, p.96) affirms that in the expression of: "Every Christian is someone else's priest, and we are all priests to one another." The benefit of this notion towards the African ecclesiology would be the advancement of an ecclesiology whose advocacy is the participation of all to the exclusion of none thus bringing every member on board in terms of contribution towards the wider good of the entire congregation.

This was in line with the confrontation of the now predominant privilege of the priesthood that they were the ones with the monotony of making intercessions for the masses. Luther expressed his understanding of the church as the community of saints by describing priesthood as the law of the church's life according to Althaus and Schultz (1966, p. 313). For Luther, the priesthood meant that we stand before God, pray for others, intercede with and sacrifice ourselves to God and proclaim the word to one another as per Althaus and Schultz (1966, p. 313-314). Althaus and Schultz (1966) in their interpretation of the position held by Luther observe that 'the individual stands directly before God; he has received the authority of substitution. The priesthood means the congregation and the priesthood is the inner form of the community of saints.'

\section{Every Christian}

Is someone else's priest, and we are all priests to one another

We are priests as $[\mathrm{H}]$ e is Priest, sons as $[\mathrm{H}] \mathrm{e}$ is Son, kings as $[\mathrm{H}] \mathrm{e}$ is King. Moreover

Every member of the Gemeine has an equal share in this priesthood. This means that

The priestly offices are the common property of all Christians, not the special

Prerogative of a select caste of holy men.

The ecclesiology of John Calvin (1960, p.4.1.1, 4) was hinged on the assertion that the church not only is the body of Christ but is also our mother, a concept that he borrows from the third-century bishop of Carthage, Cyprian, famously who said: "He does not have God for his Father who does not have the church for his mother." That phrase and the manner he accorded emphasis on the fact that "there is no salvation outside the church" were repeated by Calvin almost word for word. Calvin's (John Calvin, The Institutes of the Christian ReJohn T. McNeill ed., 1960) tradition is known to grant significant emphasis on the notion that there is no provision for private Christianity as there can only be and which is the ideal communal Christianity. The composition of the church according to Calvin (1960, p.4.1.2) is what informs his emphasis that we need to exercise caution that we do not believe in the church. This is because the church is comprised of people like you and me and to level trust on the same would be misguided because of our inclination to sin. But borrowing from the mother analogy, he captures the church as the community of faithful followers of Christ in which we are spiritually conceived, born, and raised. Barth correctly affirms in his description of the church as the "cultural and historical environment of Jesus" as is elaborated in Guder and Guder (2004, p. 255). Our observation of ecclesiology beyond the reformation will be captured in the approaches that the discipline of ecclesiology has taken and the input of scholarship in all those approaches. In this area, we shall explore the literature available on the Orthodox ecclesiology, Roman Catholic ecclesiology, Reformed ecclesiology, and Pentecostal and Charismatic ecclesiology. 


\section{Ecclesiological Approaches of Various Confessional Traditions}

There have been variances with regard to conversations and dialogues of ecclesiology on the basis of affiliation to various church organizations. Karkkainen (2002, p. 15-17) follows the natural way of doing ecclesiologies which is the introduction of major theological and confessional traditions that emerged during church history. As regards the confessional traditions such as Eastern Orthodoxy, Roman Catholicism, Lutheranism, and the Reformed Family has a straightforward task because each of these traditions has established doctrines and views of the church. Eastern orthodox theology has a strong orientation from the Eastern fathers of the church. Eastern theology has been considered generally to be more 'Spirit-sensitive' than the Western counterparts whose theology is built on Christological concept rather than on Pneumatological. Volf (1998, p.129) has captured a position that integrates the two as this Spiritmediated relationship with the triune God and with the entire history of God's people- a history whose Centre resides in Jesus' own proclamation of the reign of God, in his death and his resurrection is what constitutes an assembly into a church.

The balance and governor of the Eastern thought to safeguard it from an over-emphasis on the Spirit is her emphatic assertion of the centrality of the Father in the doctrine of the Trinity (Kärkkäinen, 2002). There is a strong sense of consciousness of the Eastern ecclesiology of understanding a church in terms of a community. Volf (1998, p.130) highlights on the character of the presence of the Spirit and its external condition give to an ecclesiology its specific configuration; it is these two factors that determine the constellation of relationships between individual persons and the local church, and between the local churches as such. Ware (1993, p.240) observes this concept in the notion of the statement: "We know that when any of us falls, he falls alone; but no one is saved alone. He is saved in the church, as a member of it and in union with all its other members."

This brings out the understanding that in as much as the Christian is saved individually the envisioned end of the journey is a state where the individuals come to a place of communion with other believers.
Karkkainen (2002, p.18) observes that this is only attainable when believers are in fellowship with other believers and is totally unattainable in isolation. This ideology is the backbone of the concept of Ubuntu to bring out the best in the community by outright advocacy for structured community and formalized relationships. Thus, an African ecclesiological conversation should not in any way exclude the concepts of community and relationships as pillars of her establishment. According to Orthodox ecclesiology, which understands itself as being wholly Eucharistic, the church is episcopocentric because, on the one hand, the bishop as alter Christus mediates the presence of Christ and secures the catholicity of the local church and on the other hand as alter apostolus he connects all the various local churches in time (apostolicity) and space (conciliarity) in the sentiments of Volf (1998, p.148). Ware (1999, p.107-108) is also in agreement and further emphasizes that the Orthodox tradition in its signature consciousness has in her heart the ecclesial character of all true Christians.

Therefore, the function and position of the bishop are critical and indispensable for both the Eucharistic gathering and ecclesiality of the local church (Volf, 1998). Volf (1998) argues further that this constructs the understanding that there cannot be any local church that is not incorporated in the communion of the orthodox churches that can be granted the status of a church, despite the fact that the local assembly would be in right standing with regard to the apostolic succession because it lacks synchronic communion with other churches. This brings to our attention the ecclesiology that will nourish in Africa and steer the church towards growth and stability is an ecclesiology that appreciates the task of ecumenical contribution towards the advancement of God's kingdom in Africa. The trademark of the perception of those from the East on matters pertaining to church anchored on its soteriological understanding that is not focused on guilt concepts and $\sin$ but on progressive development in sanctification culminating in the adherent attainment of union with divinity and the acquisition of a new-found status that resembles God, a position that is crucial in the crafting of her ecclesiological understanding in a profound way (Kärkkäinen, 2002). 
The Roman Catholic Church is currently the world's leading Christian body in terms of numerical value and claims a great historical involvement and growth of tradition over two millennia. Its Christological ecclesiology is seen in the position that without an acknowledgment of Christ, there is no church in the expression of Volf (1998, p. 129). According to Avery Dulles (1974, chpt. 3) one of the models of the church is the church as 'mystical communion' departing from both the sociological theory and protestant ecclesiologies arguing that catholic ecclesiology of communion goes back to the New Testament witness and was never abandoned, even though at times other models towered over it. It is noteworthy to state that similar to the Orthodox Church, Roman Catholic ecclesiology centers around the people as is stated by Volf (1998, p. 131). McDonnell (1988, p. 674) builds on the debate affirming that if one is to attest truly to the dynamics of Acts, immediately after the Spirit would be the concept of koinonia or communion. This he believes is a community formation together with its Eucharistic expression observing that the signature of Luke in Acts is one of communion. Zizioulas (1985, p.156) contributes on the same in his expression that the communion thematic approach that was primal, specifically the expression of the Eucharist constructed the ecclesiological dialogue that prevailed in most of the earliest councils.

Luther's ecclesiology is accurately captured with an understanding that he had to fight an ecclesiastical system that digressed from its course and was taking stances that were contrary to biblical sanctions. Luther was very aggressive in his assertion that there was no need for practices that were then identical of the Roman Catholic Church as intercession by priests, monks or masses, prayers for the dead saints, penance and indulgence. Congar (1997, p. 139-140) concurs with this that Luther had to contend with the Catholic position that, according to Luther's interpretation, held the church and its hierarchical structure as absolute. Luther was a staunch believer that all that was needed was faith nourished by the Word of God that was accurately captured in his famous theme of "justification by faith". In Romans 3:21-22 Luther is said to have found the solution to the problem of sin that was integrated in the concept of passive righteousness according to Spickard \& Cragg (1994, p. 174). This concept according to him was that humanity was helplessly evil until God's nature changed their essential nature and this influenced his understanding of Christianity and subsequently the church (Spickard \& Cragg, 1994).

Luther understood the church to comprise a community of the saints and sinners. Karkkainen (2002, p.41) gives an analysis that this approach of understanding the church by Luther is realistic in that he takes it for granted that this church of Christ as presently constituted is the communion of saints and is also always the communion of sinners, until the Lord of the Church will return. In this respect, there is no way for humans to distinguish between the true followers of Christ and the wicked in the church as articulated by Karkkainen (2002, p.42). By the 1550s and 1560s, Spickard \& Cragg (1994, p. 184) affirm that the energies of the original Reformers had begun to dissipate and the one who took the lead in the second generation of the Reformation was John Calvin (1509-1564). Calvin observed the church as a primarily visible community and this he strongly envisioned in the growing emphasis of the public appropriation of the sacraments, especially of the baptism according to Karkkainen (2002, p.51). Calvin as captured by Riggs (1995, p. 37-38) used the analogy of the 'mother' to describe the church in terms of her role to the faithful through whom one has rebirth and salvation and at the same time emphasizing her public ministry and church discipline.

\section{Contextual Ecclesiologies}

The dedication of this segment is to unearth the spirited commitment among ecclesiological scholars with regard to the ecclesiologies of three specific cultural geographical environments of Africa, Asia, and Latin America. These are areas of significance in ecclesiological conversations by virtue of the growth of Christianity and Christian churches in these regions in the last century. For the limitation of time, we shall evaluate the situation in Latin America and Africa. To begin with let us observe the Latin American ecclesiology that is mainly Catholic base communities that is a signature of church life among Hispanics as is well articulated by Karkkainen (2002, p.164). Boff (1986, p.1) on the same has observed that we are slowly but with an ever-increasing intensity 
witnessing the establishment of communities where people are actually known and recognized and where they on their individual capacity can have their voices heard and be welcomed by name and thus the mushrooming of groups and little communities a concept that is seen in the church where we have grassroots Christian communities or the basic church communities.

Cook (1985, p. 11-85) has analytically outlined two significant reasons that are behind the emergence and the rapid growth of these communities in the Latin American Roman Catholic Church. The first is that these communities were a response to the absence of the community concept in the wider society and specifically the Roman Catholic Church. The lack of community in the Roman Catholic Church in Latin America has also been captured by (Boff, 1986) in his remark that the church drifted towards 'an organizational form with a heavily hierarchical framework and a juridical understanding of the relationship among Christians thus producing mechanical, reified inequalities and inequities." The second reason was the contextual problem then of poverty and marginalization and segregation of some in the society (Cook, 1985). Karkkainen (2002, p.177) is in agreement that these base communities championed for the struggle for freedom and liberation. This serves as a classic illustration of the necessity of an ecclesiology that engages in dialogue with context to be in a better place to present an ecclesiology that better addresses the need of her audience.

Theologically these communities as fronted by (Boff, 1986) the pioneer of the movement deserve to be welcomed, contemplated, and accorded respect as agencies of salvific events as they have a strong bearing of ecclesiastical elements. It is also of great significance to elaborate that beyond their argument for the church ecclesiality, these groups project for a specific type of ecclesiality of the birthing of the church community 'from below' from the people of God. Thus, the interpretation of the expression is a spirited effort to trigger the strength of the community aspect for the people (Kärkkäinen, 2002). He (Kärkkäinen) further elaborates that this horizontal dimension captures the concept of God's calling on humanity towards mutual respect, generosity, a communion of believers, and simplicity in the relationship. This is because the church that is sprung from the people has the same authority and character as that of the apostles (Boff, 1986).

This emphasis of Latin ecclesiology draws strong similarity with the philosophy behind the Ubuntu concept that saw the Africans 'finding their identity and meaning of life through their existence in the extended family, clan, and tribe' according to O'Donovan (1996, p.4). The truth in Africa is captured in the understanding: "I am because the community is" captured by the Ubuntu passionate affection towards common participation in the life, common history, and common destiny (O'Donovan, 1996). Similar values celebrated within the Latin America community ecclesiology are identical to the Ubuntu emphasis on empathy, congruence, and open communication and oppose in the strongest terms inward, selfish egoism as the enemy of community life as is stated by Makhudu (1993, p. 40-41). There is also a similarity in the manner in which communities in Latin America and Ubuntu in the means of the adoption of an anthropocentric approach giving greater priority to people as is stressed by Broodryk (2005, p.15). Also identical with the Latin American context is the similarity of challenges that are prevalent in the African continent. We are plagued with the problems of poverty and the seemingly quick departure from our traditional communal framework that held the community together towards individualism.

In African ecclesiology, the dominant force has been the African Independent Churches (AICs) that have the signature of the Koinonia, a catchword for much ecumenical ecclesiology since the 1980s. To understand these AICs, Omenyo (fall, 2000, p.235236) insists that it is paramount to acknowledge the community dimension of the African communities. This philosophy that governs the holistic lifestyle of the African people could not be expressed in any better phrase as is embodied in the statements: "I am because we are, and since we are, therefore I am" from Mbiti (1989, p.106). Antwi (1996, p. 10) on the concept of community has asserted that it is deeply embedded in the African conviction that people can only find the true meaning of life in the framework of a community. Waliggo in Mugambi \& Magesa (1990, p.117) affirm that there has been a steadfast appeal among African theologians stressing the need of evolving Africa's own model 
of the church because none of the models given by the theologians of the West are acceptable.

Waliggo (Mugambi \& Magesa, 1990) further observes that it is the community model that envisions the church as a community of people promoting people's growth with the fellowship of brotherhood and sisterhood structured as a mechanism for the human growth of all people. Beyond the embrace of the African concept of community, Omenyo (fall, 2000, p.238) states that the AICs facilitate the provision of a model of a caring Christian community that was identical to the early apostolic church in Acts 2:42 enhancing community life. Karkkainen (2002, p. 198) is in agreement that naturally the worship design of the AICs is very communal; it is also spontaneous and engaging as it employs the rich musical and artistic heritage of African cultures. He also confirms that there is a strong emphasis on participation by all, not only the clergy are encouraged to participate.

We are priests as $[\mathrm{H}]$ e is Priest, sons as $[\mathrm{H}]$ e is Son, kings as $[\mathrm{H}] \mathrm{e}$ is King. Moreover

Every member of the Gemeine has an equal share in this priesthood. This means that

The priestly offices are the common property of all Christians, not the special

Prerogative of a select caste of holy men.

We are priests as $[\mathrm{H}] \mathrm{e}$ is Priest, sons as $[\mathrm{H}] \mathrm{e}$ is Son, kings as $[\mathrm{H}] \mathrm{e}$ is King. Moreover

Every member of the Gemeine has an equal share in this priesthood. This means that

The priestly offices are the common property of all Christians, not the special

Prerogative of a select caste of holy men.

\section{Ubuntu}

Shutte (2001, p.9) explains Ubuntu as a concept that can and is not restricted to any region in the world as it can be practiced universally. This is because in as much as it is an African ideological thought the embodiment of principle and comprehension embedded in it is universal in scope breaking any regional barriers and providing humanity in her totality with a tool to overcome the great division witnessed in our world today. This brings to the attention of this study the need to accord some time to the understanding of an African philosophy because the concept of Ubuntu has been conceptualized as a philosophy of the African people. The mention of African philosophy has elicited a heated argument among the academia with three categories of response according to the evaluation of Lajui (2014, p.2): the first category doubt the existence of African philosophy; the second category accept the idea of African philosophy but uncritically equate proverbs, folktales, and other African value systems to philosophy; lastly are those of the belief that it is high time for Africans to develop and show the world the existence of world view, systems of governance, and way of behaviour informed or based on identifiable theories, principles and consistent explanations that are not necessarily equated by other non-African ways of looking at things.

Father Placide Frans Tempels (1959, p.21) acknowledged as a pioneer of the conversation of Bantu (African) Philosophy questions if the Bantu philosophy has been developed and studied as such and the need of all scholars to seek out and define the fundamental thought underlying Bantu ontology the only key that allows native thought to be penetrated. It is this existing ontology that penetrates and informs all the thoughts of these primitives dominates and orients all their behaviour (Templels, 1959). Masolo (1994, p. 47) notes that according to Tempels, the entire system of Bantu thought based on this ontology is philosophy even as he acknowledges the difficulty to convince his (Tempels') readers who were missionaries and colonial administrators. According to Tempel in Imbo (1998, p.11), despite criticism as to why he was the one behind the formulation of the Philosophy without the involvement of the Bantu, he affirmed that the proof that complex ontological ideas are indeed held implicitly by the Bantu is that when he submitted his formulation of Bantu Philosophy to the people themselves, they agreed that he had correctly stated what they meant.

Another contributor to the conversation of African philosophy was one; Leopold Sedar Senghor a Senegalese statesman credited for crafting a 
negritude theory another variation on the theme of ethnophilosophy (Imbo, 1998). He grounded his socio-political philosophy of negritude in the idea that the African experience of the world is based on emotions, not reason according to Imbo (1998, p. 12). The emphasis of negritude was a consciousness of the world through the medium of emotion, and the expression of emotion is at the center of African culture and that Africans in their languages, experiences, and cultures demonstrate a distinct mode of apprehension holding that Africans were different from but not inferior to Europeans thus he led the negritude movement of philosophers, anthropologists, and poets in defending an unscientific, unanalytical and untechnical African mind (Imbo, 1998).

Alexis Kagame (1919-1981) a Roman Catholic priest from Rwanda also significantly contributed to linguistic ethnophilosophy emending Tempels' ontology through his linguistic analysis of the Rwandan language, affirming an African difference and suggesting an 'original formative environment' unique to the African mode of thinking according to Odhiambo (2008, p. 124). This study is in agreement that to this end, ethnophilosophers have been on the forefront to make a bold statement especially directed to their European counterparts that Africans have their system of thought that reveals a system of the philosophy of religion and of cosmology similar to that of Europeans and it is rightly referred as 'Ethnophilosophy' because of its spirited endeavour to translate the African ethic thought into categories and language of Western philosophy with chief proponents as John Mbiti of Kenya, Alexis Kagame of Rwanda, Tempels and Marcel Griaule of France in the sentiments of South African Council of Churches (2007, Issues 127132).

This understanding then places the concept of Ubuntu as a significant philosophy incumbent on the African people. The available literature on the subject of Ubuntu, according to Resane (2017, p. 94), is extensive both in secular and religious initiatives or activities. The development of the concept traces back to many centuries in traditional African culture and this culture was pre-literate, prescientific, and pre-industrial and it found its expressions in the songs, sayings, parables, stories, customs, and institutions of the people as is captured by Shutte (2001). This has made this Ubuntu concept to find expressions in different means depending on the context of the one expressing it. From a political perspective, Maritain (1943, p. 10) made the expression of politics that the utopian political setting that is desired by any human society is one which is steadfast to prioritize human worth as the common goal. For this model to be realized then the role of the judicial function cannot be underestimated because it serves as an anchor to achieve real humanity and community.

Shutte (2001, p.184) states that in a country that is alive with Ubuntu the government will reflect a climate of public opinion as a crucial entity and is firmly dependent on the real values of the people. This will bring a strong sense of reciprocity between the people and those in authority, no feelings of "them" and "us" but mutual respect and reverence. People will trust those in authority because of their personal qualities, not simply because of their power. Those in authority will exercise freedom in their governance because as they honestly judge best, they genuinely aim to govern for the essence of the common good. It is Ubuntu that is able then from such expressions to trigger a sense of patriotism because as Sheed (1953, p. 169) affirms that by nature love is felt more intensely at the center and most intensely for those close to us and less intense as we move outwards. He continues that the man who lacks love for his country is a diminished man: not so diminished as if he lacked love for his family, but there is less to him all the same.

The church leadership and governance can borrow a leave from the Ubuntu policy on governance. It calls for inclusivity and participation that will enhance a sense of patriotic love for all members of the church. Problems that are prevalent in our continent with regard to politics and governance thrive squarely from the fact that in our failure to look at politics and governance in the eye of Ubuntu. Vices such as corruption and massive misappropriation of funds are tendencies that are anti-Ubuntu because they fail to serve the ultimate purpose of governance which is the common good of the people. The trait of Ubuntu in governance is marked by integrity, cohesion, and inclusivity. Matters marginalization, tribalism, and ethnic balkanization do not serve the common good of any 
people. Eliastam $(2015$, p.2) connects Ubuntu to governance and politics in the following expressions: a constitutional value that can be operationalized in law and a philosophical basis for constitutional democracy.

The Ubuntu ethic in education is also captured among many scholars on the subject as cited in Murray Ed. (1997, p.83). Aristotle affirms that a state must be a plurality that must be united into a community by education. From these sentiments, we capture the correlation that exists between community and education being one of dependence. The strength of any community is defined by the establishment of its structure on matters of education. No wonder Nelson Madiba Mandela said, "Education is the most powerful weapon which you can use to change the world" as quoted by Antoine (2018, p.94). That is why accurate education is not limited to the school environment but comprises both family and societal institutions. This could not be expressed in more uncertain terms as highlighted by Shutte (2001, p.107) describing the evident relationship between the family and the people that is very complex because of its nature of being very basic. Both institutions: families and society have an authentic authority especially with regard to their roles as educators.

We know the centrality of personal growth incumbent on education thus making it not only a temporal initiative but permanent in the sense that it is a lifelong endeavor. If the gravity accorded to education is anything to go by, then the seriousness we consider institutions that are involved as education agencies will be higher from early childhood to adulthood. The church plays a critical role in all these stages. Then Ubuntu emerges as a normative for education and a guiding principle for citizenship education (Eliastam, 2015). Therefore, it can be confirmed that a good education serves the best interest of the community in its entirety without any biases whatsoever.

Lastly in this segment, we look at the scholarship of the Ubuntu concept in the work philosophy and its relevant implication. Schumacher (1979, p.118) approaches the functionality of work from its threefold dimension to the individual: grants all an equal opportunity to employ and nurture their capacities, to cause the imminent downfall of all egocentric tendencies inherent in all by their vivid participation in common initiatives geared towards the strife of the common good and need a desired descent existence. The fact that it brings people together for a common task and serves the interest of all is a summary of the concept of Ubuntu. All work brings people together as work is the natural space for the community to develop, and that is why it is an important part of life as expressed by Shutte (2001, p. 161). The African view of personhood and ethics of work does not in any way esteem or undermine anyone based on their work. Our nature of being anthropocentric makes people more important than any other thing work included. Pope John Paul (1981) the Second also expressed in his own way that works is for man and not man for the work. Having observed in brief the way the Ubuntu concept is diverse in the sense of its influence on man we desire to now change gear and center around its influence on the religious and theological dimension.

Eliastam (2015) quotes the understanding of Tutu that Ubuntu is to a large extent a theological motif and that of Forster defines it as a framework for the theology of relational ontology. Elie Buconyori ed. (1977, p.18) connects the Concept of Ubuntu to the wa kwetu (homeboy) both to the religious paradigm of the African people in the sentiments: "to the extent that wa kwetu is taken as a social bonding that gives community's social identity, economic security, religious guidance, and a sense of belonging, it is to be affirmed. After all, to be human is to belong. Christianity advances an ideology that thrives on the desire to give consideration to the interest of others above the personal interest. The core value of Ubuntu according to Resane (2017, 97) is that individualism is self-fatalism and the submissive mental attitude resulting from acceptance of the doctrine that everything that happens is predetermined and inevitable finding no space in Ubuntu lifestyle because everything that happens to the individual is to have a bearing in the community.

Africans have been considered to be socially gregarious and this expression finds demeanour in the setting of the community. This is seen in many of the rites of passage that are expressed and conducted in the communal atmosphere. Boon (1998, p.33) contributes to this notion that the 
formulation of the Ubuntu philosophy is anchored on the values such as openness, sharing, and welcome all demonstrated in many ways and particularly through weddings. In traditional African society, there are open weddings where everyone in the community was aware of the engagement as it is publicly announced by the raising of a white flag. The wedding date is then carefully monitored and on an eventful day, anyone who likes to come to the wedding is welcomed. But people do not arrive empty-handed besides the gift for the bridal couple, they bring beer and food and they join in the celebration. A religious perspective that is Ubuntu will have the unlimited transcendence power that is the ground of being present in all one is and does and this will be manifest in the manner with which one relates with other persons because it is here that it is able to empower personal growth and bring about personal community as is narrated by Shutte (2001, p. 204).

Salvation in the African mindset according to Lang (1994, p. 153), is seen in the incorporation of the individual into the common life of the whole community of the living and dead and through that community, the rest of the cosmos with God. The expression could not be more clear than the affirmation that salvation is a move from individualism to the community, from hostility to hospitality, from material poverty to material prosperity; sickness to health, from vulnerability to the power of witches to protection against their power, from unfaithfulness to integrity, from death to life, salvation is for this life as is asserted by Iloanusi (1984, p. 224). It is apparently clear that salvation from an African perspective is closely linked to the community.

Traditionally in the African setting, the concept of Ubuntu brought a sense of cooperation among the members of a community as people were brought together for joint initiatives for the purposes of assisting one in the community. Ubuntu emphasis is on synergy, cooperation, symbiosis, and mutualism as correctly articulated by Resane (2017, 99). (Resane, 2017) Defines synergism as that working together in an effort to produce an effect greater than what an individual could accomplish on his or her own. While attesting to the fellowship dimension of AICs, Nthamburi in Mugambi \& Magesa (1990, p. 44-45) acknowledges that Africans live in close-knit communities where relationships are jealously guarded because to be in fellowship with one another is to have a common bond that unites the individual to a cohesive group were individualism withers away. It is in this perspective that the main objective of the church should be a shift towards a participatory community where discipline, selfcontrol, purity of life, and tolerance make it possible for all members to work together for the Kingdom of God according to (Mugambi J.N.K. \& Magesa Laurenti Eds., 1990).

Steve Biko emphasizes the concept in his argument of the active role expected of beneficiaries in the joint venture of the African community to avoid the dependency syndrome. He states that even ordinary ventures in the society such as agriculture, the building of homes, and rites of passages though conducted at the familial level, were seen to demand communal participation. Any member of the society cherished the presence and participation of neighbours' that were just a mere request away for any needed assistance in the land without any thought of any monetary payment to them other than a commitment to participate in their ventures as well as cited by Okonkwo (2010, p. 2010, 137:96).

It is in this understanding that we can establish that 'Ubuntu is indeed some synergy and cooperation for co-existing harmonious relations, where people live for one another articulated by Resane $(2017,100)$. According to Stott (2007, p.96) koinonia is an objective fact expressing what we share. Tutu in his acknowledgment that Ubuntu theology builds an interdependent community analyses the South African experience of Apartheid reflecting that its spirit is that people exist to be divided, segregated and marginalized and exclusivity in contrast to the spirit of the Scripture that advances ideologies of togetherness and people are made for fellowship (Resane, 2017).

\section{Conclusion}

Our study began by locating the scholarship on ecclesiology with regard to how it has been constructed within different church epochs from the patristic era to the medieval era towards the reformation era and beyond. This led us towards ecclesiological scholarship from the perspective of key personalities in this era such as Martin Luther, 
John Calvin, and Ulrich Zwingli. These personalities influenced greatly the trajectory of ecclesiological scholarship. Beyond the reformation, our study captured the approaches that the discipline of ecclesiology has taken and the input of scholarship in all those approaches of various confessional traditions. Our interaction with contextual ecclesiology exposed us to the commitment among ecclesiological scholars with regard to the ecclesiologies of three specific cultural geographical environments of Africa, Asia, and Latin America. The due focus was accorded to African ecclesiology in an attempt to link all the discussed ecclesiologies with the African Christian thought. Scholarship engagement that has been conducted with regard to the Ubuntu concept was also reviewed and we were able to capture the concept of the humanness of people in the African setting. Our study has exposed a gap in the literature demonstrating that the African conceptual framework can indeed be of use in articulating theology relevant to the African world. This can be achieved through the contribution towards the development and construction of an African ecclesiology using the Ubuntu concept as a remedy to solve ecclesiological problems witnessed in Africa.

\section{REFERENCES}

Antoine, B. (2018). 2014: The Year of Action: Two leaders of the 21st century in the White House and the Vatican express politically and spiritually their views of compassion and humility in their quest for equality and justice. Pittsburgh, PA.: Dorrance Publishing Co.

Antwi, J. D. (1996). Sense of Community: An African Perspective of the Church as Koinonia. Trinity Journal of Church and Theology (6) 10.

Ayittey George. (2006). "Indigenous African Institutions: 2nd Edition." Brill.

Boff, L. (1986). Ecclesiogenesis: The base communities reinvent the church. Orbis Books.

Boon, M. (1998). The African Way: The Power of Interactive Leadership (Sandton.
Broodryk, J. (2005). Ubuntu management philosophy: Exporting ancient African wisdom into the global world. Knowres Publishing.

Congar, M. J. (1965). The idea of the church in St. Thomas Aquinas. Thomist: A Speculative Quarterly Review, 1, 331.

Congar, Y. (1997). I believe in the Holy Spirit. Crossroads.

Cook, G. (1985). The Expectation of the Poor: Latin American Basic Ecclesial Communities in Protestant Perspective." Maryknoll, N.Y.: Orbis.

Dulles, A. (1974). Models of the Church. Garden City, New York: Doubleday.

Dulles, A. (1982). The Church according to Thomas Aquinas. New York: Crossroad.

Eliastam, J. L. (2015). Exploring ubuntu discourse in South Africa: Loss, liminality and hope. Verbum et Ecclesia, 36(2), 1-8.

Buconyori, E. A. (ed.). (1977). "Tribalism and Ethnicity." Nairobi: The AEA Theological and Christian Education Commission.

Evans, R. (1972). One and Holy. London: SPCK.

George, T. (1988). Theology of the Reformers (Nashville, Tenn.

Grant, R. M. (1977). Early Christianity and society. Religious Studies, 15(4).

Haight, R. (2004). Christian Community in History. Historical Ecclesiology, Vol. 1. New York: Continuum.

Hippolytus. (1962). "The Apostolic Tradition of Hippolytus." Cambridge: Cambridge University Press.

Iloanusi, O. A. (1984). Myths of the creation of man and the origin of death in Africa: a study in Igbo traditional culture and other African cultures. Lang.

Imbo, S. O. (1998). An Introduction to African Philosophy.: Okot p'Bitek's legacy for African philosophy. Rowman \& Littlefield.

35 | This work is licensed under a Creative Commons Attribution 4.0 International License. 
Jaki, S. (1957). Les tendances nouvelles de l'ecclesiologie. Bibliotheca Academiae Catholic ae Hungaricae/Sectio philosophico-theologica.

John Calvin, The Institutes of the Christian ReJohn T. McNeill ed. (1960). "John Calvin, The Institutes of the Christian Religion, trans. Ford Lewis Battles." Philadelphia: Westminister Press.

Joseph, L. (2014). The medieval church: a brief history. Routledge.

Kalilombe, P. (1977). Building Christian Communities. Lumen Vitae, 185.

Kärkkäinen, V. M. (2009). An introduction to ecclesiology: Ecumenical, historical \& global perspectives. InterVarsity Press.

Kelly. J. D. N. (1960). Early Christian Doctrines 2nd ed." London.

Lajui Wilfred. (2014). “African Philosophy: Critical Dimensions.” Kampala: Fountain Publishers.

Lang Peter. (1994). "Being Human in Africa: Towards an African Christian Anthropology." New York: Peter Lang Publishing.

Mugambi, J. K., \& Magesa, L. (1990). The church in African Christianity: Innovative essays in ecclesiology.

Makhudu, N. (1993). Cultivating a climate of cooperation through ubuntu. Enterprise Magazine, 48, 40-42.

Maritain Jacques. (1943). "Education at the Crossroads." Yale: New Haven.

Mbiti, J. S. (1989). African religions \& philosophy. Heinemann.

McDonnell, K. (1988). Communion ecclesiology and baptism in the spirit: Tertullian and the early church. Theological Studies, 49(4), 671-693.

Mugambi J.N.K. \& Magesa Laurenti Eds. (1990). "The Church in African Christianity: Innovative Essays in Ecclesiology." Nairobi: Initiatives.

Mugambi, J. N. K. (1997). The church and reconstruction of Africa: Theological considerations. All Africa Conference of Churches.

Mutiso-MbindaJ. (1979). Pastoral Anthropology and the Church. "Spearhead 60", 48.

Ochieng'-Odhiambo F., Roxanne Burton, Ed Brandon. (2008). "Conversations in Philosophy: Crossing the Boundaries." Cambridge: Cambridge Scholars.

O'donovan, W. (1996). Biblical Christianity in African Perspective. Paternoster.

Okonkwo, I. (2010). The sacrament of the Eucharist (as Koinonia) and African sense of communalism: Towards a synthesis. Journal of Theology for Southern Africa, (137), 88.

Omenyo, C. N. (2000). Essential aspects of African ecclesiology: the case of the African independent churches. Pneuma, 22(1), 231-248.

Patrick Murray Ed. (1997). "Reflections on Commercial Life: An Anthology of Classic Texts from Plato to the Present." New York: Routeledge.

Paul, A. (1966). The Theology of Martin Luther. Fortress Press.

Paul, S. R., Cragg, K. M., \& Carlson, G. W. (1994). A global history of Christians: How everyday believers experienced their world. Baker Academic.

Poovan, N., Du Toit, M. K., \& Engelbrecht, A. S. (2006). The effect of the social values of ubuntu on team effectiveness. South African Journal of Business Management, 37(3), 17-27.

RahnerK. (1961). "Theological Investigations." London: London Press.

Resane, K. T. (2017). Communion ecclesiology in a racially polarised South Africa. Sun Press.

Riggs, J. W. (1995). Emerging Ecclesiology in Calvin's Baptismal Thought, 15361543. Church history, 64(1), 29-43.

Rwelamila, P. D., Talukhaba, A. A., \& Ngowi, A. B. (1999). Tracing the African Project Failure

36 | This work is licensed under a Creative Commons Attribution 4.0 International License. 
Syndrome: the significance of 'ubuntu'. Engineering, Construction, and Architectural Management.

SchumacherFritz. (1979). "Good Work." London: Cape.

Sheed, F. (1953). "Society and sanity." London: Sheed and Ward.

Shutte, A. (2001). Ubuntu: An ethic for a new South Africa.

South African Council of Churches. (2007,127:132). Journal of Theology for Southern Africa. "Issues 127-132": 41.

Stott, J. (2007). Evangelical Truth: a personal plea for unity, integrity, and faithfulness. Langham Global Library.

Templels Placide. (1959). "Bantu Philosophy: Collection Presence africaine." Presence africaine Ed.

Volf, M. (1998). After our likeness: The church as the image of the trinity. Pro Ecclesia, 9(1), 112114.

Ware Kallistos. (1993). "The Orthodox Church, rev. ed.” London: Penguin.

William A. Dyrness, Veli-Matti Kärkkäinen (2009). Global Dictionary of Theology: a resource for the worldwide Church. InterVarsity Press.

Zizioulas John. (1985). "Being as Communion: Studies in Church and Personhood." New York: St. Vladimir's Seminary Press. 